\title{
Saccharibacillus kuerlensis sp. nov., isolated from a desert soil
}

\author{
Correspondence \\ Ren Lai \\ rlai72@njau.edu.cn
}

\author{
Shou-Yun Yang, ${ }^{1} \dagger$ Huan Liu, ${ }^{2,3} \dagger$ Rui Liu, ${ }^{1}$ Ke-Yun Zhang ${ }^{1}$ and Ren Lai ${ }^{1,2}$
}

${ }^{1}$ Key Laboratory of Microbiological Engineering of Agricultural Environment, Ministry of Agriculture, Life Sciences College of Nanjing Agricultural University, Nanjing, Jiangsu, 210095, PR China

${ }^{2}$ Biotoxin Department of Key Laboratory of Animal Models and Human Disease Mechanisms, Kunming Institute of Zoology, Chinese Academy of Sciences, Kunming, Yunnan, 650223, PR China

${ }^{3}$ Graduate School of the Chinese Academy of Sciences, Beijing 100009, PR China
The genus Saccharibacillus of the family 'Paenibacillaceae' was first proposed by Rivas et al. (2008) to include a Gramvariable, facultatively anaerobic, motile and rod-shaped bacterium that was negative for catalase and oxidase activities and that had anteiso- $\mathrm{C}_{15: 0}$ as the main fatty acid and menaquinone-7 as the major respiratory menaquinone. At present, the genus comprises only one species, Saccharibacillus sacchari.

In our search for organisms capable of growing in desert ecosystems, a bacterial strain, designated $\mathrm{HR} 1^{\mathrm{T}}$, was isolated from a soil sample collected from the southern desert of Kuerle $\left(41^{\circ} 46^{\prime} \mathrm{N} 86^{\circ} 07^{\prime} \mathrm{E}\right)$, a city at the heart of Xinjiang, the most westerly province of China. The combination of phenotypic and chemotaxonomic characteristics, phylogenetic analysis based on $16 \mathrm{~S}$ rRNA gene sequences and DNA-DNA hybridization showed that strain $\mathrm{HR} 1^{\mathrm{T}}$ is a representative of a novel species of the genus Saccharibacillus.

Strain $\mathrm{HR} 1^{\mathrm{T}}$ was isolated using the standard dilutionplating technique on Luria-Bertani (LB) agar medium. The isolate was cultivated routinely on $\mathrm{LB}$ agar at $30{ }^{\circ} \mathrm{C}$ under aerobic conditions and maintained as a glycerol suspension

†These authors contributed equally to this work.

The GenBank/EMBL/DDBJ accession number for the $16 \mathrm{~S}$ rRNA gene sequence of strain $\mathrm{HR} 1^{\top}$ is EU046270.
$(20 \%, w / v)$ at $-70{ }^{\circ} \mathrm{C}$. Biomass for molecular systematic and chemotaxonomic studies was obtained by culturing strain $\mathrm{HR} 1^{\mathrm{T}}$ in liquid $\mathrm{LB}$ medium and harvesting the cells by centrifugation.

Amplification and sequencing of the 16S rRNA gene was performed as described by Cui et al. (2001). The sequence obtained was compared with available 16S rRNA gene sequences retrieved from GenBank using the BLAST program (http://www.ncbi.nlm.nih.gov/blast/) to determine an approximate phylogenetic affiliation. Phylogenetic analysis was performed using the software packages PHYLIP (Felsenstein, 1993) and MEGA version 3.1 (Kumar et al., 2001) after multiple alignment of the data by CLUSTAL_X (Thompson et al., 1997). Distances (distance options according to Kimura's two-parameter model; Kimura, $1980,1983)$ and clustering were based on the neighbourjoining (Saitou \& Nei, 1987), maximum-likelihood (Felsenstein, 1981) and maximum-parsimony (Kluge \& Farris, 1969) methods. Bootstrap analysis (1000 replications) was used to evaluate the topology of the neighbourjoining tree (Felsenstein, 1985).

The almost-complete 16S rRNA gene sequence of strain $\mathrm{HR}_{1}^{\mathrm{T}}$ (1513 bp) revealed the highest similarity to $S$. sacchari LMG $24085^{\mathrm{T}}$ (97.9\%); the sequence similarities to members of other genera of the family 'Paenibacillaceae' with validly published names were lower than $93.4 \%$. 
Phylogenetic trees obtained with different algorithms were identical with respect to the position of strain $\mathrm{HR} 1^{\mathrm{T}}$, which formed a distinct branch with its closest relative $S$. sacchari LMG $24085^{\mathrm{T}}$. A phylogenetic tree based on the neighbourjoining algorithm is shown in Fig. 1.

Genomic DNA was extracted and purified according to Yoon et al. (1996) and the DNA G+C content was determined using the thermal denaturation method (Mandel \& Marmur, 1968). The $\mathrm{G}+\mathrm{C}$ content of the DNA was $50.5 \mathrm{~mol} \%$, which is slightly lower than the value recorded for S. sacchari LMG $24085^{\mathrm{T}}$ ( $57.8 \mathrm{~mol} \%$; Rivas et al., 2008). DNA-DNA hybridization was carried out to evaluate the genomic DNA relatedness between strain $\mathrm{HR} 1^{\mathrm{T}}$ and S. sacchari LMG $24085^{\mathrm{T}}$ by applying the optical renaturation rate method as described by De Ley et al. (1970) with the modifications described by Huß et al. (1983) and Escara \& Hutton (1980). Renaturation rates were computed with the program TRANSFER.BAS (Jahnke, 1992). The DNA-DNA relatedness between strain HR $1^{\mathrm{T}}$ and its closest relative S. sacchari LMG $24085^{\mathrm{T}}$ was $29.6 \%$. According to Stackebrandt \& Goebel (1994) and Wayne et al. (1987), the values for 16S rRNA gene similarity $(<97 \%)$ and DNA-DNA relatedness $(<70 \%)$ support the genomic distinction of strain $\mathrm{HR} 1^{\mathrm{T}}$ from S. sacchari $\mathrm{LMG}$ $24085^{\mathrm{T}}$.

For quantitative analysis of the cellular fatty acid content, cells were harvested after 2 days growth at $30{ }^{\circ} \mathrm{C}$ on tryptic soy agar (Merck) and fatty acid methyl esters were prepared and identified by following the instructions of the Microbial Identification system (MIDI) as described by Sasser (1990). The type strain of the closely related species S. sacchari (LMG $24085^{\mathrm{T}}$ ) was also cultured under the same nutrient and temperature conditions and characterized concurrently with strain $\mathrm{HR} 1^{\mathrm{T}}$. Determination of the cellwall peptidoglycan was performed using the methods of Schleifer \& Kandler (1972). Polar lipids were extracted, examined by two-dimensional TLC and identified following Minnikin et al. (1984). Menaquinones were analysed as described by Komagata \& Suzuki (1987) using reversedphase HPLC. The cellular fatty acids of strain $H R 1^{\mathrm{T}}$ are listed in Table 1 and compared with S. sacchari LMG $24085^{\mathrm{T}}$. Anteiso- $\mathrm{C}_{15: 0}$, the major fatty acid found in $S$. sacchari LMG $24085^{\mathrm{T}}$ (Rivas et al., 2008), was also the major fatty acid component of strain $\mathrm{HR}^{\mathrm{T}}$, comprising $50.3 \%$ of the total. The peptidoglycan type was mesodiaminopimelic acid, in line with all other members of the family 'Paenibacillaceae', which includes the genus Saccharibacillus. The predominant isoprenoid quinone was MK-7, which supports the affiliation of strain $H R 1^{T}$ to the genus Saccharibacillus; in addition, a small amount of MK-6 was detected. This profile is slightly different from that of S. sacchari LMG $24085^{\mathrm{T}}$, in which small amounts of both MK-6 and an unidentified menaquinone were detected (Rivas et al., 2008). The polar lipids of strain $\mathrm{HR} 1^{\mathrm{T}}$ are diphosphatidylglycerol, phosphatidylglycerol and an unknown phosphoglycolipid. Glycolipids and aminophospholipids, which occur in S. sacchari LMG $24085^{\mathrm{T}}$,

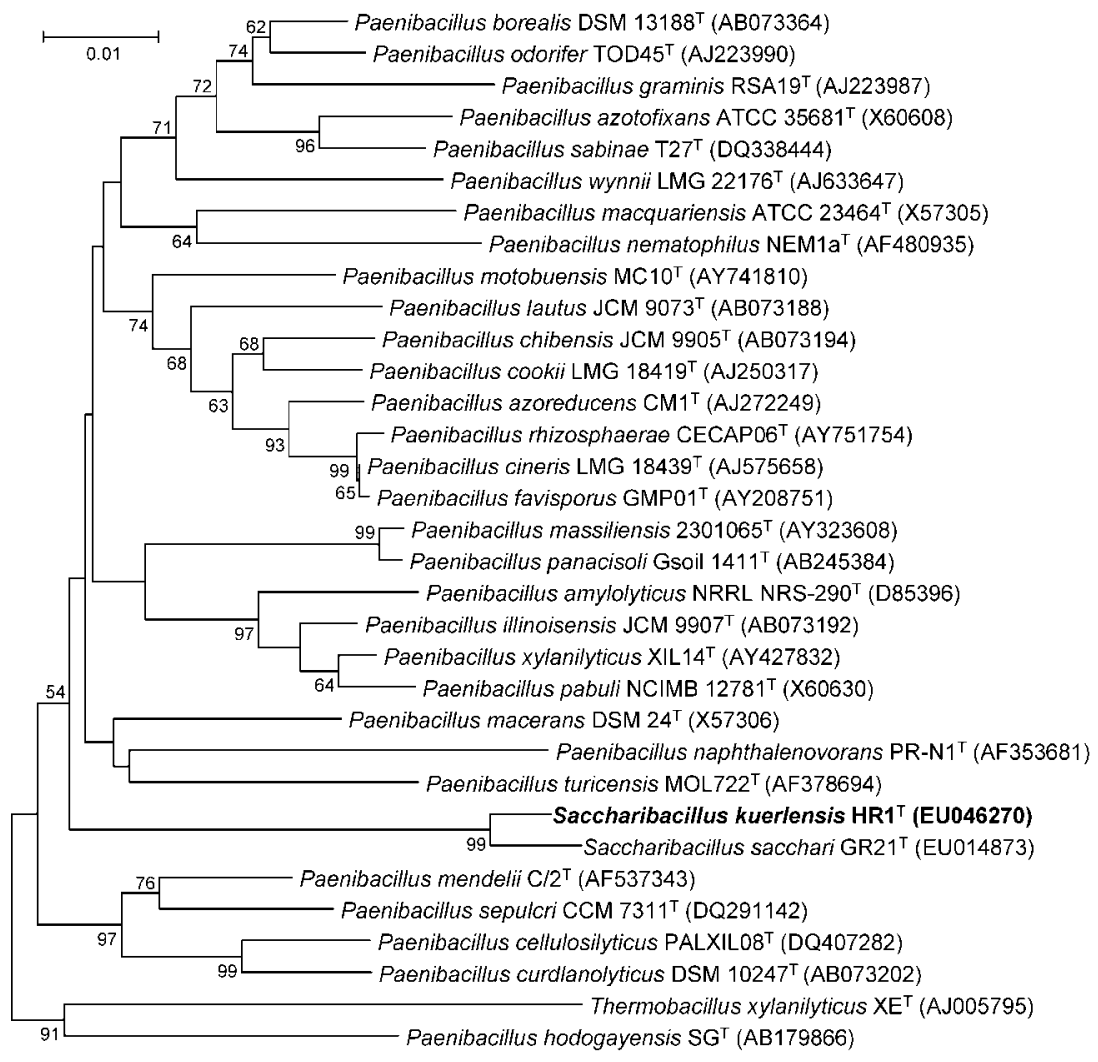

Fig. 1. Phylogenetic tree obtained by neighbour-joining analysis based on 16S rRNA gene sequences, showing the position of strain $\mathrm{HR}^{\top}$ among phylogenetically related species. Numbers on branch nodes are bootstrap values (1000 resamplings). Bootstrap values $>50 \%$ are shown at branch points. Bar, 0.01 substitutions per nucleotide position. 
Table 1. Fatty acid profiles of strain $\mathrm{HR}^{\top}$ and $S$. sacchari LMG $24085^{\top}$

Data were taken from present study. Values are percentages of total fatty acids. -, Not detected; fatty acids amounting to less than $1.0 \%$ in both strains are not listed.

\begin{tabular}{|c|c|c|}
\hline Fatty acid & Strain HR1 ${ }^{\mathrm{T}}$ & 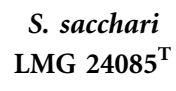 \\
\hline iso- $\mathrm{C}_{13: 0} 3-\mathrm{OH}$ & - & 3.3 \\
\hline iso- $\mathrm{C}_{14: 0}$ & 0.4 & 8.1 \\
\hline iso- $\mathrm{C}_{15: 1} \mathrm{~F}$ & - & 3.1 \\
\hline anteiso- $\mathrm{C}_{15: 1} \mathrm{~A}$ & - & 1.1 \\
\hline iso- $\mathrm{C}_{15: 0}$ & 1.3 & 2.1 \\
\hline anteiso- $\mathrm{C}_{15: 0}$ & 50.3 & 44.4 \\
\hline $\mathrm{C}_{16: 1} \omega 11 c$ & 9.0 & - \\
\hline $\mathrm{C}_{16: 1} \omega 7 c$ alcohol & 2.3 & - \\
\hline iso- $\mathrm{C}_{16: 0}$ & 0.5 & 12.4 \\
\hline $\mathrm{C}_{16: 0}$ & 2.8 & 12.0 \\
\hline iso- $\mathrm{C}_{17: 1} \omega 10 c$ & 1.7 & - \\
\hline iso- $\mathrm{C}_{17: 0}$ & 0.5 & 1.6 \\
\hline anteiso- $\mathrm{C}_{17: 0}$ & 4.5 & 4.0 \\
\hline $\mathrm{C}_{18: 1} \omega 9 c$ & 5.9 & 1.0 \\
\hline $\mathrm{C}_{18: 1} \omega 5 c$ & - & 1.4 \\
\hline $\mathrm{C}_{18: 0}$ & 1.2 & 1.7 \\
\hline Summed feature $3^{*}$ & 1.4 & 0.7 \\
\hline Summed feature $4^{*}$ & 16.8 & - \\
\hline
\end{tabular}

${ }^{\star}$ Summed feature 3 contains $\mathrm{C}_{16: 1} \omega 7 c$ and/or iso- $\mathrm{C}_{15: 0}$ 2-OH. Summed feature 4 contains iso- $\mathrm{C}_{17: 1} \mathrm{I}$ and/or anteiso- $\mathrm{C}_{17: 1} \mathrm{~B}$.

and phosphatidylethanolamine, which occurs in members of other genera of the family 'Paenibacillaceae', were not detected. However, strain $\mathrm{HR}^{\mathrm{T}}$ contained the unknown phosphoglycolipid that is present in S. sacchari LMG $24085^{\mathrm{T}}$ but has not been reported in other genera. This polar lipid profile provided decisive evidence that strain $\mathrm{HR} 1^{\mathrm{T}}$ belongs to the genus Saccharibacillus and is different from other related species.

Morphological features were examined by using light microscopy (model BH 2; Olympus) and transmission electron microscopy (Hitachi-7650) after 24 h growth on $\mathrm{LB}$ agar at $30^{\circ} \mathrm{C}$. For transmission electron microscopy observation, cells were negatively stained with $1 \%(\mathrm{w} / \mathrm{v})$ phosphotungstic acid and, after air drying, Gram-staining and endospore formation were investigated as described by Smibert \& Krieg (1994). Growth at different temperatures and $\mathrm{pH}$ values was investigated as described by $\mathrm{Xu}$ et al. (2005), using LB broth as the basal medium. $\mathrm{NaCl}$ tolerance was tested using LB broth supplemented with 0 , $1,2,3,5$ and $6 \% \mathrm{NaCl}$, respectively. Growth was determined on cetrimide agar, Simmons' citrate agar, MacConkey agar and nutrient agar. All tests were incubated at $30{ }^{\circ} \mathrm{C}$ for 2 days. Antibiotic sensitivity tests were performed using the diffusion method on LB agar at $30{ }^{\circ} \mathrm{C}$ with filter-paper discs ( $8 \mathrm{~mm}$ diameter) containing one of the following antibiotics: amoxicillin $(10 \mu \mathrm{g})$, ampicillin $(10 \mu \mathrm{g})$, carbenicillin $(100 \mu \mathrm{g})$, cefamezin $(30 \mu \mathrm{g})$, ceftazidime $(30 \mu \mathrm{g})$, chloramphenicol $(30 \mu \mathrm{g})$, erythromycin $(15 \mu \mathrm{g})$, gentamicin $(10 \mu \mathrm{g})$, kanamycin $(30 \mu \mathrm{g})$, ofloxacin $(5 \mu \mathrm{g})$, penicillin $\mathrm{G}(10 \mathrm{IU})$, polymyxin B $(30 \mu \mathrm{g})$, rifampicin $(5 \mu \mathrm{g})$, streptomycin $(10 \mu \mathrm{g})$, tetracycline $(30 \mu \mathrm{g})$ and vancomycin $(30 \mu \mathrm{g})$. After 2 days of incubation, the diameters of the inhibition zones were measured. Acid production from carbohydrates was determined using the medium and methods described by Yamaguchi \& Yokoe (2000). Single carbon-source utilization was determined as described by Liu et al. (2008). Oxidase activity was tested by determining the oxidation of $1 \%(\mathrm{w} / \mathrm{v})$ tetramethyl-p-phenylenediamine (Merck) and catalase activity was evaluated by determining the production of oxygen bubbles in a $5 \%(\mathrm{v} / \mathrm{v})$ aqueous hydrogen peroxide solution. Phenylalanine deaminase activity and hydrolysis of Tweens 80 and 20, aesculin, DNA and CMcellulose were investigated as described by Smibert \& Krieg (1994). Urease activity and hydrolysis of casein, gelatin, tyrosine and starch were determined as described by Cowan \& Steel (1965). Some other biochemical characteristics were tested using API 20E kits (bioMérieux) according to the instructions of the manufacturer. Cells of strain $\mathrm{HR}^{\mathrm{T}}$ stained Gram-positive and were motile, sporulating rods with a single lateral flagellum, about 0.4$0.5 \mu \mathrm{m}$ wide and $0.8-1.4 \mu \mathrm{m}$ long (Fig. 2). Colonies were convex, almost-circular, opaque, non-glossy and pink after $48 \mathrm{~h}$ of incubation at $30^{\circ} \mathrm{C}$. Phenotypic features of strain $H R 1^{\mathrm{T}}$ are given in the species description and in Table 2.

In the light of the combined phylogenetic, biochemical and morphological data, strain $\mathrm{HR}^{\mathrm{T}}$ should be classified as the type strain of a novel species within the genus Saccharibacillus, for which the name Saccharibacillus kuerlensis sp. nov. is proposed.

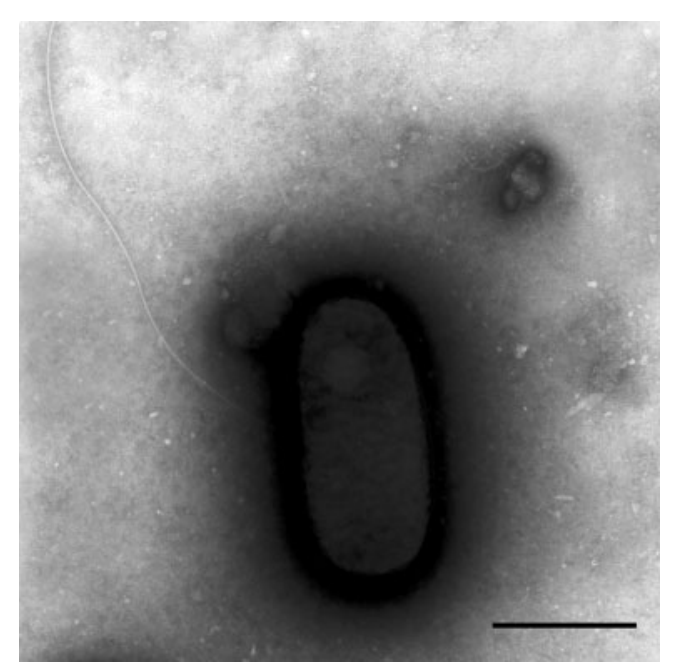

Fig. 2. Transmission electron micrograph of a cell of strain $H R 1^{\top}$ grown on LB agar for $24 \mathrm{~h}$ at $30^{\circ} \mathrm{C}$, showing the single lateral flagellum. Bar, $500 \mathrm{~nm}$. 
Table 2. Differentiating characteristics of $\mathrm{HR}^{\top}$ and $S$. sacchari LMG $24085^{\top}$

Data for S. sacchari LMG $24085^{\mathrm{T}}$ were taken from Rivas et al. (2008).

\begin{tabular}{|lcc|}
\hline Characteristic & Strain HR1 & $\begin{array}{c}\text { S. } \text { sacchari } \\
\text { LMG } 24085^{\mathbf{T}}\end{array}$ \\
\hline Growth at: & - & + \\
$8{ }^{\circ} \mathrm{C}$ & + & - \\
$42{ }^{\circ} \mathrm{C}$ & + & - \\
Tolerance of $5 \% \mathrm{NaCl}$ & + & - \\
Catalase & + & - \\
Arginine dihydrolase & - & - \\
Hydrolysis of CM-cellulose & & - \\
Utilization of: & + & - \\
D-Xylose & + & - \\
N-Acetyl-D-glucosamine & + & - \\
L-Arabinose & & - \\
Acid production from: & + & 57.8 \\
D-Mannose & + & \\
Maltose & + & \\
D-Mannitol & 50.5 & \\
DNA G+C content (mol\%) & & \\
\end{tabular}

\section{Description of Saccharibacillus kuerlensis sp. nov.}

Saccharibacillus kuerlensis (ku.er.len'sis. N.L. masc. adj. kuerlensis pertaining to Kuerle, a city of Xinjiang Province in the north-west of China where the type strain was isolated).

Gram-positive-staining, aerobic, rod-shaped cells, 0.4$0.5 \mu \mathrm{m}$ wide and $0.8-1.4 \mu \mathrm{m}$ long, motile by a single lateral flagellum. Spores are oval and subterminal and occur in unswollen sporangia. After 2 days incubation on LB agar, colonies are $1.0-2.0 \mathrm{~mm}$ in diameter, convex, almost-circular, opaque, non-glossy and pink-pigmented. Grows at $15-42{ }^{\circ} \mathrm{C}$ (optimum, $30-37{ }^{\circ} \mathrm{C}$ ), $\mathrm{pH} 5.0-10.0$ (optimum, pH 6.0-8.0) and 0-5\% NaCl. Good growth occurs on nutrient agar, but not on Simmons' citrate agar, MacConkey agar or cetrimide agar. Nitrate is reduced to nitrite. Tween 20 and aesculin are hydrolysed, but starch, casein, gelatin, DNA, Tween 80 , tyrosine and CM-cellulose are not. Positive for catalase, arginine dihydrolase, $\beta$ galactosidase and the methyl red reaction. Negative for oxidase, arginine decarboxylase, lysine decarboxylase, ornithine decarboxylase, urease, indole and hydrogen sulphide production, phenylalanine deaminase and the Voges-Proskauer reaction. Acid is produced from Dglucose, D-lactose, trehalose, D-fructose, D-xylose, L-rhamnose, maltose, raffinose, melibiose, cellobiose, melezitose, D-mannose, D-ribose, D-galactose, sucrose, turanose, Dmannitol, inositol, amygdalin, salicin and dextrin. Utilizes L-arabinose, L-arabitol, adonitol, acetate, inulin, gluconate and $\mathrm{N}$-acetyl-D-glucosamine, but not L-sorbose, xylitol, Dsorbitol, i-erythritol, glycerol, methyl $\alpha$-glucoside or tartrate. Resistant to streptomycin, but sensitive to amoxicillin, ampicillin, carbenicillin, cefazolin, ceftazidime, chloramphenicol, erythromycin, gentamicin, kanamycin, ofloxacin, penicillin $\mathrm{G}$, polymyxin $\mathrm{B}$, rifampicin, tetracycline and vancomycin. The peptidoglycan type is mesodiaminopimelic acid. The main phospholipid is diphosphatidylglycerol and MK-7 is the major isoprenoid quinone. The DNA $\mathrm{G}+\mathrm{C}$ content of the type strain is $50.5 \mathrm{~mol} \%$. The fatty acid profile is shown in Table 1 .

The type strain, $\mathrm{HR}^{\mathrm{T}}\left(=\mathrm{KCTC} 13182^{\mathrm{T}}=\mathrm{JCM} 14865^{\mathrm{T}}\right.$ $=$ CGMCC $1.6964^{\mathrm{T}}$ ), was isolated from a desert soil sample collected from Xinjiang Province, China.

\section{Acknowledgements}

We thank the Chinese National Natural Science Foundation (30600001) and Jiangsu Natural Sciences Foundation (BK2005422) for financial support. We are also grateful to Soon-Wo Kwon and Che Ok Jeon for their excellent technical assistance.

\section{References}

Cowan, S. T. \& Steel, K. J. (1965). Manual for the Identification of Medical Bacteria. London: Cambridge University Press.

Cui, X. L., Mao, P. H., Tseng, M., Li, W. J., Zhang, L. P., Xu, L. H. \& Jiang, C. L. (2001). Streptomonospora salina gen. nov., a new member of the family Nocardiopsaceae. Int J Syst Evol Microbiol 51, 357-363.

De Ley, J., Cattoir, H. \& Reynaerts, A. (1970). The quantitative measurement of DNA hybridization from renaturation rates. Eur $J$ Biochem 12, 133-142.

Escara, J. F. \& Hutton, J. R. (1980). Thermal stability and renaturation of DNA in dimethyl sulfoxide solutions: acceleration of the renaturation rate. Biopolymers 19, 1315-1327.

Felsenstein, J. (1981). Evolutionary trees from DNA sequences: a maximum likelihood approach. J Mol Evol 17, 368-376.

Felsenstein, J. (1985). Confidence limits on phylogenies: an approach using the bootstrap. Evolution 39, 783-791.

Felsenstein, J. (1993). PHYLIP (phylogeny inference package), version 3.5c. Distributed by the author. Department of Genome Sciences, University of Washington, Seattle, USA.

Huß, V. A. R., Festl, H. \& Schleifer, K. H. (1983). Studies on the spectrophotometric determination of DNA hybridization from renaturation rates. Syst Appl Microbiol 4, 184-192.

Jahnke, K. D. (1992). BASIC computer program for evaluation of spectroscopic DNA renaturation data from Gilford System 2600 spectrophotometer on a PC/XT/AT type personal computer. J Microbiol Methods 15, 61-73.

Kimura, M. (1980). A simple method for estimating evolutionary rates of base substitutions through comparative studies of nucleotide sequence. J Mol Evol 16, 111-120.

Kimura, M. (1983). The Neutral Theory of Molecular Evolution. Cambridge: Cambridge University Press.

Kluge, A. G. \& Farris, J. S. (1969). Quantitative phyletics and the evolution of anurans. Syst Zool 18, 1-32.

Komagata, K. \& Suzuki, K. (1987). Lipid and cell-wall analysis in bacterial systematics. Methods Microbiol 19, 161-207.

Kumar, S., Tamura, K., Jakobsen, I.-B. \& Nei, M. (2001). MEGA2: molecular evolutionary genetics analysis software. Bioinformatics 17, $1244-1245$. 
Liu, H., Liu, R., Yang, S.-Y., Gao, W.-K., Zhang, C.-X., Zhang, K.-Y. \& Lai, R. (2008). Flavobacterium anhuiense sp. nov., isolated from field soil. Int J Syst Evol Microbiol 58, 756-760.

Mandel, M. \& Marmur, J. (1968). Use of ultraviolet absorbancetemperature profile for determining the guanine plus cytosine content of DNA. Methods Enzymol 12B, 195-206.

Minnikin, D. E., O'Donnell, A. G., Goodfellow, M., Alderson, G., Athalye, M., Schaal, A. \& Parlett, J. H. (1984). An integrated procedure for the extraction of bacterial isoprenoid quinones and polar lipids. J Microbiol Methods 2, 233-241.

Rivas, R., Garcia-Fraile, P., Zurdo-Piñeiro, J. L., Mateos, P. F., Martínez-Molina, E., Bedmar, E. J., Sánchez-Raya, J. \& Velázquez, E. (2008). Saccharibacillus sacchari gen. nov., sp. nov., isolated from sugar cane. Int J Syst Evol Microbiol 58, 1850-1854.

Saitou, N. \& Nei, M. (1987). The neighbor-joining method: a new method for reconstructing phylogenetic trees. Mol Biol Evol 4, 406-425.

Sasser, M. (1990). Identification of bacteria by gas chromatography of cellular fatty acids. USFCC Newsl 20, 16.

Schleifer, K. H. \& Kandler, O. (1972). Peptidoglycan types of bacterial cell walls and their taxonomic implications. Bacteriol Rev 36, 407-477.

Smibert, R. M. \& Krieg, N. R. (1994). Phenotypic characterization. In Methods for General and Molecular Bacteriology, pp. 607-654. Edited by P. Gerhardt, R. G. E. Murray, W. A. Wood \& N. R. Krieg. Washington, DC: American Society for Microbiology.
Stackebrandt, E. \& Goebel, B. M. (1994). Taxonomic note: a place for DNA-DNA reassociation and 16S rRNA sequence analysis in the present species definition in bacteriology. Int J Syst Bacteriol 44, 846849.

Thompson, J. D., Gibson, T. J., Plewniak, F., Jeanmougin, F. \& Higgins, D. G. (1997). The CLUSTAL_X windows interface: flexible strategies for multiple sequence alignment aided by quality analysis tools. Nucleic Acids Res 25, 4876-4888.

Wayne, L. G., Brenner, D. J., Colwell, R. R., Grimont, P. A. D., Kandler, O., Krichevsky, M. I., Moore, L. H., Moore, W. E. C., Murray, R. G. E. \& other authors (1987). International Committee on Systematic Bacteriology. Report of the ad hoc committee on reconciliation of approaches to bacterial systematics. Int J Syst Bacteriol 37, 463-464.

Xu, P., Li, W.-J., Tang, S.-K., Zhang, Y.-O., Chen, G.-Z., Chen, H.-H., Xu, L.-H. \& Jiang, C.-L. (2005). Naxibacter alkalitolerans gen. nov., sp. nov., a novel member of the family 'Oxalobacteraceae' isolated from China. Int J Syst Evol Microbiol 55, 1149-1153.

Yamaguchi, S. \& Yokoe, M. (2000). A novel protein-deamidating enzyme from Chryseobacterium proteolyticum sp. nov., a newly isolated bacterium from soil. Appl Environ Microbiol 66, 3337-3343.

Yoon, J.-H., Kim, H., Kim, S.-B., Kim, H.-J., Kim, W. Y., Lee, S. T., Goodfellow, M. \& Park, Y.-H. (1996). Identification of Saccharomonospora strains by the use of genomic DNA fragments and rRNA gene probes. Int J Syst Bacteriol 46, 502-505. 